\title{
Some Pitfalls in Welding of Duplex Stainless Steels
}

\author{
(Algumas Armadilhas na Soldagem de Aços Inoxidáveis Duplex)
}

\author{
Demian J. Kotecki ${ }^{1}$ \\ ${ }^{1}$ Retired from The Lincoln Electric Company, USA, and President of Damian Kotecki Welding Consultants, Inc., Mentor, Ohio, USA
}

\begin{abstract}
Duplex stainless steels (DSS, including super duplex stainless steels \{SDSS\}) have proven to be very useful engineering materials, albeit with somewhat different welding requirements than those of the more familiar austenitic stainless steels. Despite a generally good track record in welding of duplex stainless steels, certain pitfalls have been encountered with enough frequency that they deserve review. Inappropriate base metal specification often leads to unsuitable heat affected zone (HAZ) properties. Autogenous fusion zones are also of concern. This issue centers around nitrogen limits. The most frequently encountered is applying the UNS S31803 composition for 2205 DSS, instead of the S32205 composition. Inappropriate welding heat input arises most frequently with SDSS. While 0.5 to $1.5 \mathrm{~kJ} / \mathrm{mm}$ is a normal heat input recommendation for SDSS, either a root pass or many small beads towards the low end of this heat input range tends to result in precipitation and/or secondary austenite formation in weld metal subjected to repeated thermal cycles from multiple weld passes. Inappropriate PWHT occurs when the enhanced nickel filler metals (typically $9 \%$ Ni) are used. DSS are not normally given PWHT, but extensive forming of heads, for example, or repair welding of castings, may require a postweld anneal. Specifications such as ASTM A790 and A890 call for annealing at $1040^{\circ} \mathrm{C}$ minimum, and the fabricator tends to use temperatures close to that minimum. However, the enhanced nickel filler metals require higher temperatures to dissolve sigma phase that forms during heating to the annealing temperature.
\end{abstract}

Keywords: Duplex stainless steel, Ferrite-austenite balance, Fusion zone, Heat-affected zone, Heat input, Heat treatment, Nitrogen, Precipitation, Welding.

Resumo: Aços inoxidáveis duplex (AID, incluindo os aços super duplex, AISD) provaram ser materiais de engenharia muito úteis, embora com requerimentos de soldagem em alguma medida diferentes daqueles dos aços inoxidáveis austeníticos mais usuais. Apesar do histórico geralmente bom dos aços inoxidáveis duplex quanto a soldagem, algumas dificuldades têm sido encontradas com uma frequência relativamente alta para justificar um exame mais detalhado destas. A especificação inadequada do metal base frequentemente resulta em propriedades inadequadas da zona termicamente afetada (ZTA). Zona fundida autógena é também motivo de preocupação em função de limites no teor de nitrogênio. A situação mais comumente encontrada é o uso de UNS S31803 para o AID 2205 no lugar de S32205. O uso de um aporte térmico inapropriado ocorre mais frequentemente com AISD. Embora uma faixa de 0,5 a 1,5 kJ/mm seja uma recomendação normal de aporte térmico para AISD, tanto o passe de raiz como muitos pequenos cordões depositados no limite inferior desse intervalo de aporte térmico tendem a resultar em precipitação elou formação de austenita secundária no metal de solda submetido a ciclos térmicos repetidos. Tratamento térmico após soldagem (TTAT) inapropriado ocorre quando metais de adição de maior teor de níquel (tipicamente 9\%) são usados. Estes tratamentos não são normalmente aplicados a AID, mas a conformação severa de cabeças, por exemplo, ou a soldagem para reparo de fundidos, pode requerer um recozimento após a soldagem. Especificações como a ASTM A790 e a A890 indicam um mínimo de $1040^{\circ} \mathrm{C}$ para o recozimento e o fabricante tende a usar uma temperatura próxima deste mínimo. Contudo, o metal de adição de maior teor de níquel requer temperaturas mais elevadas para dissolver a fase sigma durante o aquecimento para a temperatura de recozimento.

Palavras Chave: Aço inoxidável duplex, balanço ferrita-austenita, zona fundida, zona termicamente afetada, aporte térmico, nitrogênio, precipitação, soldagem.

\section{Introduction}

Duplex ferritic-austenitic stainless steels have been in existence for nearly 80 years. These alloys are characterized by solidification as essentially $100 \%$ ferrite, and austenite must nucleate and grow in the solid state. Early alloys, such

(Recebido em 25/10/2010; Texto final em 11/11/2010). as the wrought alloy 329 and the cast alloy $\mathrm{CD} 4 \mathrm{MCu}$, tended to contain considerably more ferrite than austenite. In addition, the importance of nitrogen was not appreciated and many alloys contained little nitrogen [1], so that austenite nucleation and growth are often too slow under weld cooling conditions to obtain anything close to the equilibrium amount of austenite in the weld heat-affected zone (HAZ) without postweld annealing. While the weld filler metal could be over-alloyed with nickel to promote austenite formation in the fusion zone, the as-welded HAZ of such alloys tended to be brittle, with poor corrosion 
Table 1 - Composition ranges for 2205 DSS.

\begin{tabular}{|c|c|c|c|c|c|c|c|c|c|}
\hline \multirow{2}{*}{ UNS Designation } & \multicolumn{8}{|c|}{ Chemical Composition Range, Weight \% (single value is a maximum) } \\
\cline { 2 - 11 } & $\mathrm{C}$ & $\mathrm{Mn}$ & $\mathrm{P}$ & $\mathrm{S}$ & $\mathrm{Si}$ & $\mathrm{Cr}$ & $\mathrm{Ni}$ & $\mathrm{Mo}$ & $\mathrm{N}$ \\
\hline $\mathrm{S} 31803$ & 0.030 & 2.00 & 0.030 & 0.020 & 1.00 & 21.0 to 23.0 & 4.5 to 6.5 & 2.5 to 3.5 & 0.08 to 0.20 \\
\hline $\mathrm{S} 32205$ & 0.030 & 2.00 & 0.030 & 0.020 & 1.00 & 22.0 to 23.0 & 4.5 to 6.5 & 3.0 to 3.5 & 0.14 to 0.20 \\
\hline
\end{tabular}

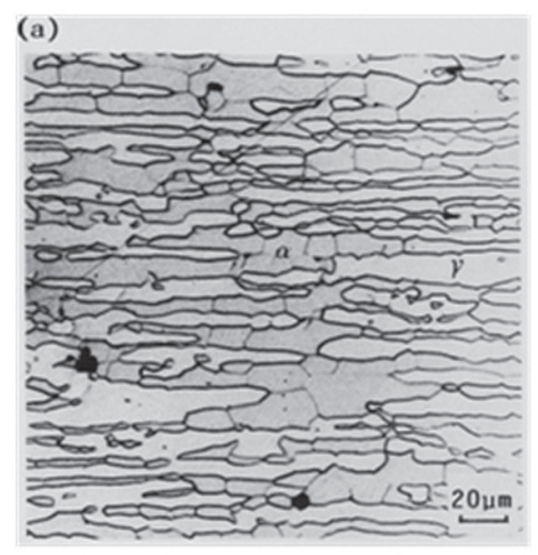

(d)

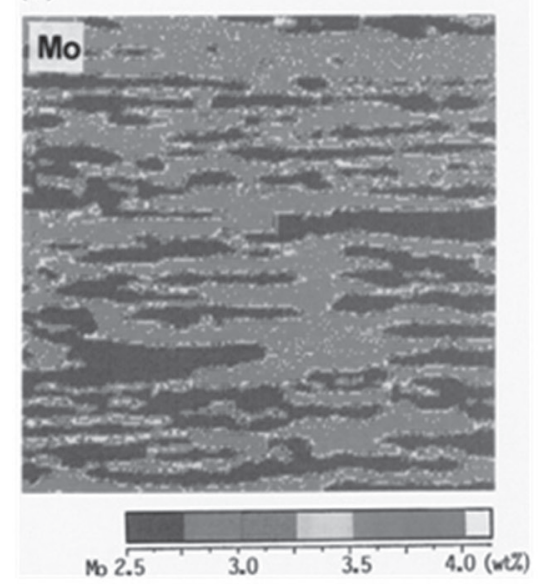

(b)

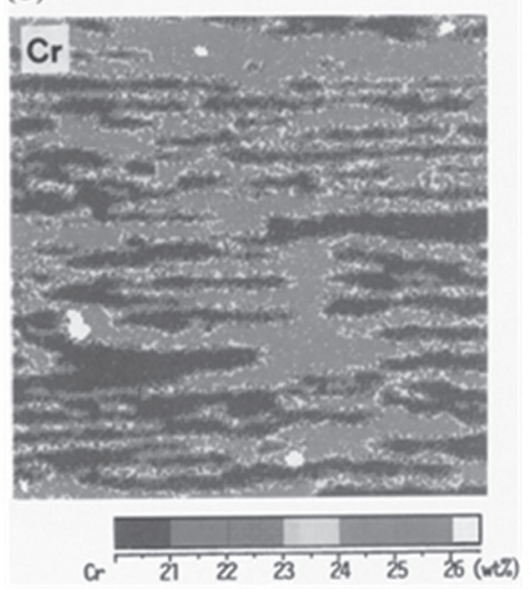

(e)

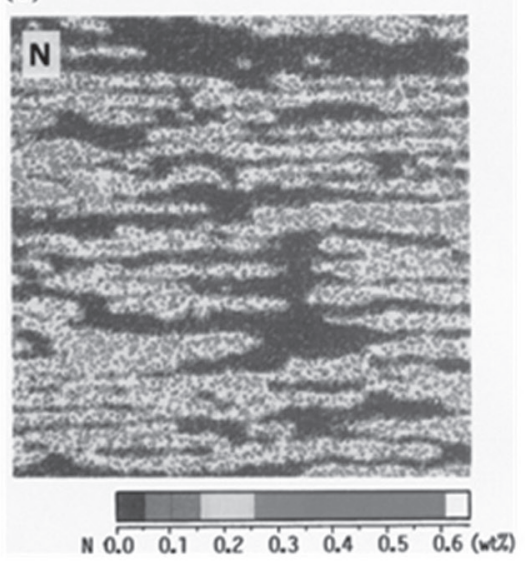

(c)

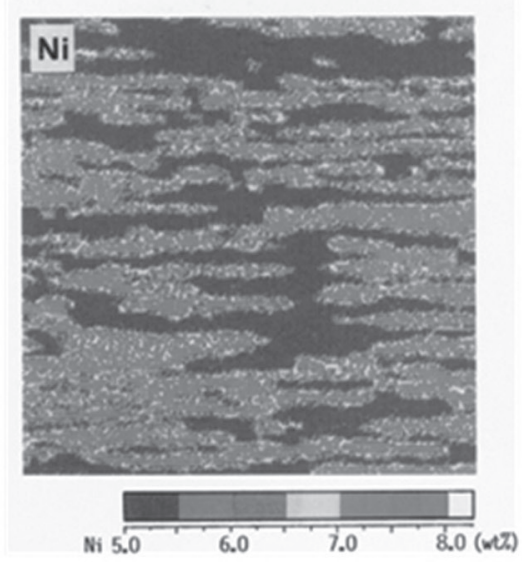

2205 Base Metal $22 \% \mathrm{Cr}$ $6 \% \mathrm{Ni}$ $3 \%$ Mo $0.12 \% \mathrm{~N}$

Figure 1. Wrought microstructure and element partitioning in UNS S31803.

resistance. Autogenous weld metal suffered from the same deficiency.

In the 1980s, the importance of nitrogen addition to the DSS base metal became fully realized, and it became normal to specify minimum nitrogen requirements. With appropriate nitrogen content in the base metal, and over-alloying with nickel in the weld filler metal, weldments with approximately equal amounts of austenite and ferrite, resulting in good mechanical properties and good corrosion resistance, could be obtained in the as-welded condition. The main limitation on the welding process then became heat input appropriate to obtain the proper austenite-ferrite balance in the HAZ by obtaining the proper cooling rate. Heat input that was too low could still result in excessive ferrite, while heat input that was too high could result in precipitation of intermetallic phases. It has become common to recommend heat input of 0.5 to $2.5 \mathrm{~kJ} / \mathrm{mm}$ for $22 \% \mathrm{Cr}$ DSS
[2], and 0.5 to $1.5 \mathrm{~kJ} / \mathrm{mm}$ for $25 \%$ Cr DSS [3].

While most duplex stainless steel weldments are put into service in the as-welded condition, there are at least two situations where postweld heat treatment (annealing) is often required. DSS castings are almost invariably annealed, and if casting defects are repaired by welding, the weld must generally be annealed also. And large welded heads that are either cold or hot formed after fabrication by welding may require annealing.

There are pitfalls for the unwary in all three of these areas: base metal specification, welding heat input limits and postweld annealing practices.

\section{Pitfall 1: Inappropriate Base Metal Specification}

For the past quarter century, probably the most popular DSS has been the alloy commonly known as 2205. The literature 
(a)

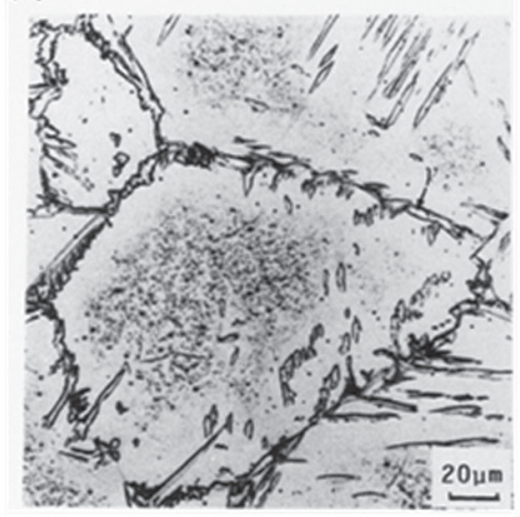

(d)

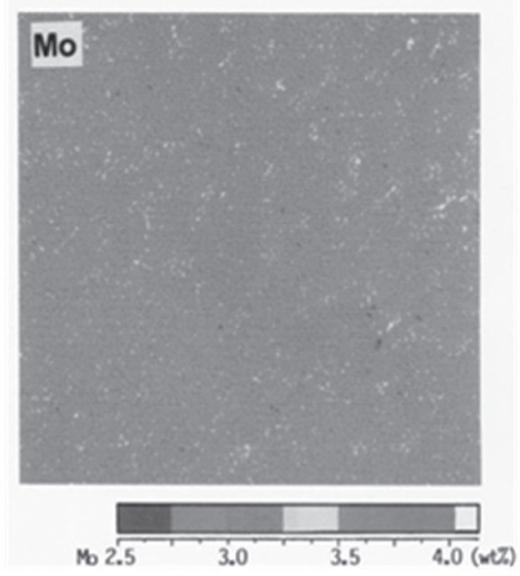

(b)

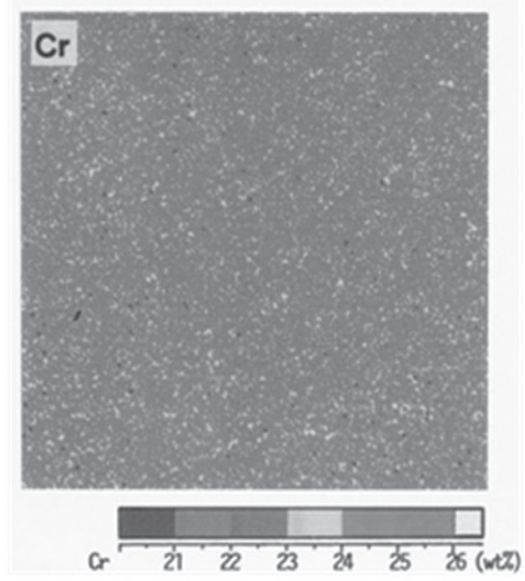

(e)

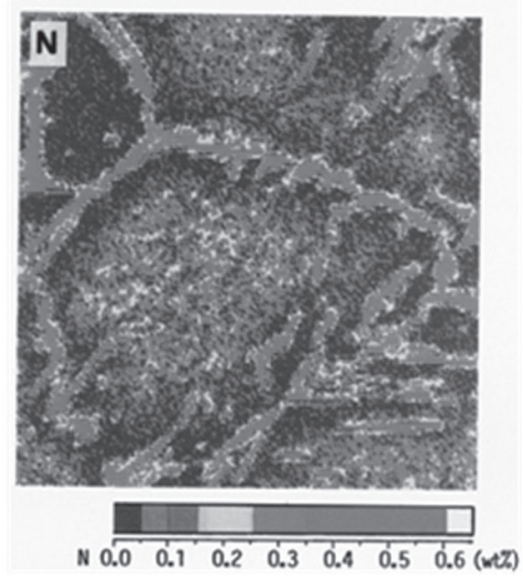

(c)

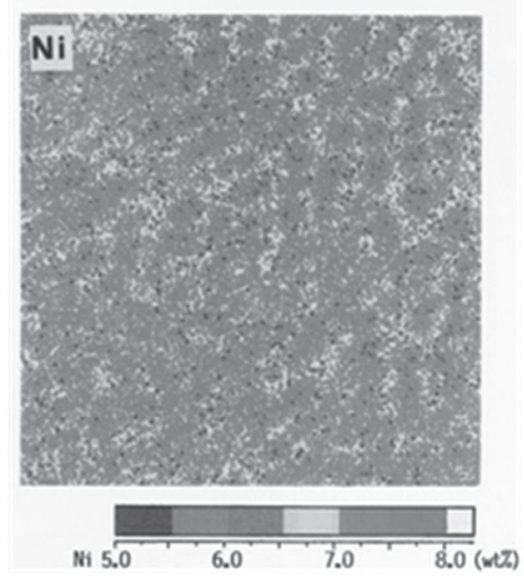

2205 Weld Metal $22 \% \mathrm{Cr}$ $6 \% \mathrm{Ni}$ $3 \%$ Mo $0.12 \% \mathrm{~N}$

Figure 2. Microstructure and element distribution of autogenous GTA weld in S31803.

is replete with descriptions of this alloy according to the UNS S31803 composition range. However, the nitrogen content associated with UNS S31803 can be as low as $0.08 \%$, a level that has proven to be too low for good HAZ and autogenous fusion zone properties in the as-welded condition. Recognizing this issue, the ASTM has instead, since the year 2000, defined 2205 by UNS S32205 [4]. Table 1 shows the composition ranges for UNS S31803 and UNS S32205. It can be noted that, in addition to the increased minimum nitrogen requirement for S32205 as compared to S31803, the minimum chromium and molybdenum limits have been increased.

The importance of nitrogen in controlling the ferrite/ austenite phase balance during welding has been well illustrated by Ogawa and Koseki [5]. Figures 1 through 3 are taken from their report. Figure 1 shows the microstructure and alloy element partitioning between the ferrite phase and the austenite phase in a wrought composition that conforms to UNS S31803 but not to UNS S32205. The nitrogen, at $0.12 \%$, is too low for the S32205 composition range. In Figure 1(a), the ferrite is the darker grey phase while the austenite is nearly white. It is readily seen that chromium and molybdenum are enriched in the ferrite phase while nickel and nitrogen are enriched in the austenite phase.

In particular, chromium content is approximately $25 \%$ in the ferrite but only $20 \%$ in the austenite \{Figure 1(b) \}, molybdenum content is approximately $3.5 \%$ in the ferrite but only $2.5 \%$ in the austenite $\{$ Figure 1(d)\}, while nickel content is approximately $7.5 \%$ in the austenite but only $5 \%$ in the ferrite \{Figure 1(c)\}, and nitrogen content is approximately $0.3 \%$ in the austenite and virtually $0 \%$ in the ferrite \{Figure $1(\mathrm{e})\}$. This is essentially the equilibrium phase distribution. It is somewhat layered because the steel has been hot rolled.

Contrast Figure 1 with Figure 2. Figure 2 shows the microstructure and alloy element distribution of the fusion zone of an autogenous GTA weld in the same UNS S31803 material as that of Figure 1. Austenite is now limited mainly to thin layers along prior ferrite grain boundaries, with a few scattered austenite platelets within the ferrite grains. The partitioning of alloy elements $\mathrm{Cr}$, Ni and Mo between ferrite and austenite is scarcely discernible. In particular, one can barely see any pattern in the distribution of these elements in Figure 2(b), 2(c) or 2(d) that resembles the distribution of the phases in Figure 2(a). However, the distribution of nitrogen shows higher concentration in the austenite platelets around the ferrite grain boundaries than within the ferrite grains. The regions beside these austenite platelets, as shown in Figure 2(e), contain virtually zero nitrogen, presumably because the nitrogen that was in those regions had enough time to diffuse to the austenite along the ferrite grain boundaries. In the interior of the ferrite 
(a)

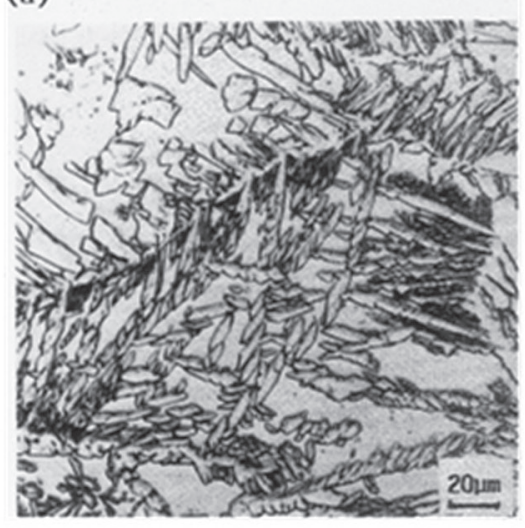

(d)

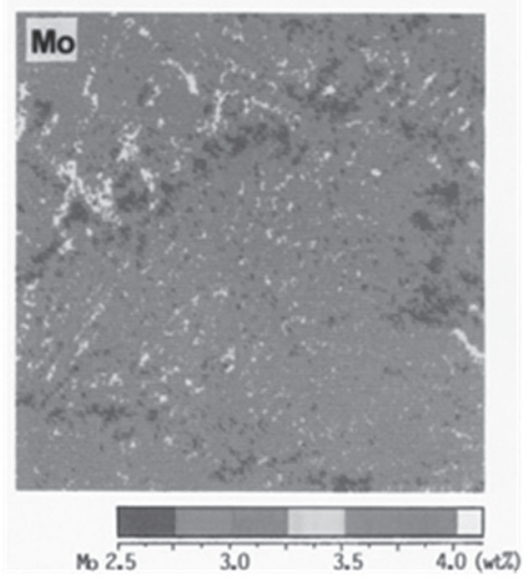

(b)

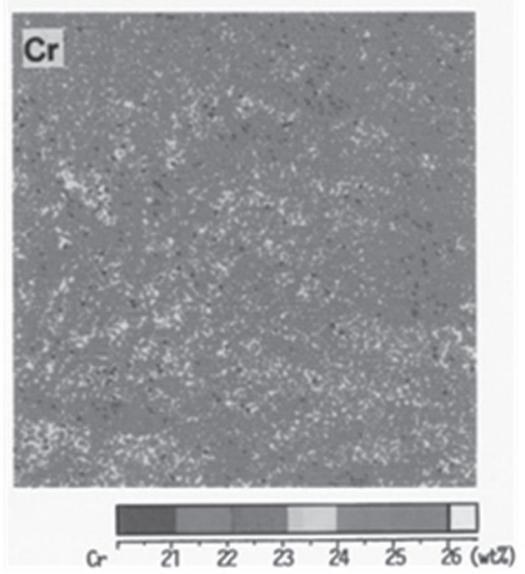

(e)

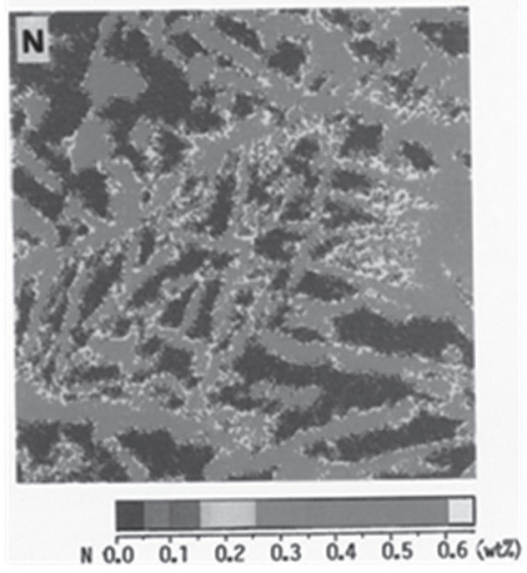

(c)

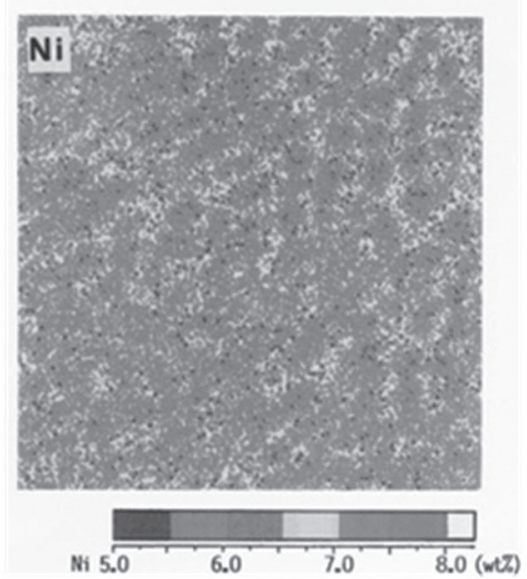

2205 Weld Metal

$22 \% \mathrm{Cr}$ $6 \% \mathrm{Ni}$ $3 \%$ Mo $0.18 \% \mathrm{~N}$

Figure 3. Microstructure and element distribution of autogenous GTA weld in S32205.

grains, where the nitrogen is trapped without access to austenite, precipitates are visible in Figure 2(a) which turn out to be chromium nitrides. The combination of the large ferrite grains and the chromium nitride precipitates is very damaging to the toughness and corrosion resistance of the fusion zone.

The fusion zone solidifies as essentially $100 \%$ ferrite, as noted previously. Then when transformation to austenite begins, diffusion is necessary. Chromium, nickel and molybdenum, being substitutional elements, diffuse relatively slowly in the solid state, so that they cannot partition between ferrite and austenite under normal weld cooling conditions. Nitrogen, however, is an interstitial element that diffuses on the order of 100 times as fast as the substitutional elements. As a result, it has some ability to partition to austenite, albeit incompletely for the composition shown in Figure 2.

The hottest part of the HAZ in this $0.12 \%$ nitrogen material behaves similarly to the weld metal. In particular, it forms virtually $100 \%$ ferrite, then must transform in part to austenite, in the solid state. So it too tends to form large ferrite grains with mainly austenite platelets forming along the prior ferrite grain boundaries. While the composition of the fusion zone can be manipulated by selection of higher nickel filler metal to speed up the formation of austenite, little can be done for the HAZ. As a result, compositions of this sort are best avoided for optimum properties in as-welded construction.

Figure 3 shows the microstructure and alloy element distribution of the GTA fusion zone of a 2205 alloy meeting the composition limits of both UNS S31803 and S32205 by virtue of its higher nitrogen content than that of the composition shown in Figure 2. The higher nitrogen content of the weld metal of Figure $3(0.18 \%$ as compared to the $0.12 \%$ of Figure 2$)$ dramatically changes the as-welded microstructure. In particular, it can be clearly seen in Figure 3(a) that much more austenite formed than in Figure 2(a), and the austenite is scattered throughout the original large ferrite grains, rather than being largely limited to the original ferrite grain boundaries.

In contrast to Figure 2(a), there are no chromium nitride precipitates to be seen in Figure 3(a). Instead, virtually all of the nitrogen has found its way to austenite, as can be seen in Figure 3(e). Furthermore, some slight partitioning of $\mathrm{Cr}$ and Mo is evident in Figure 3(b) and (d) - the areas where the first austenite formed along the original ferrite grain boundaries can be seen to be lower in $\mathrm{Cr}$ and Mo than in the remainder of the original ferrite grain. This becomes possible because the higher nitrogen content of this composition causes austenite formation to begin at a higher temperature than in the $0.12 \%$ 
Table 2. Composition limits for Alloy 255.

\begin{tabular}{|c|c|c|c|c|c|c|c|c|c|c|}
\hline \multirow{2}{*}{$\begin{array}{c}\text { UNS } \\
\text { Designation }\end{array}$} & \multicolumn{8}{|c|}{ Chemical Composition Range, Weight \% (single value is a maximum) } \\
\cline { 2 - 12 } & $\mathrm{C}$ & $\mathrm{Mn}$ & $\mathrm{P}$ & $\mathrm{S}$ & $\mathrm{Si}$ & $\mathrm{Cr}$ & $\mathrm{Ni}$ & $\mathrm{Mo}$ & $\mathrm{N}$ & $\mathrm{Cu}$ \\
\hline $\mathrm{S} 32550$ & 0.04 & 1.50 & 0.040 & 0.030 & 1.00 & 24.0 to 27.0 & 4.5 to 6.5 & 2.9 to 3.9 & 0.10 to 0.25 & 1.50 to 2.50 \\
\hline $\mathrm{S} 32520$ & 0.030 & 1.50 & 0.035 & 0.020 & 0.80 & 24.0 to 26.0 & 5.5 to 8.0 & 3.0 to 4.0 & 0.20 to 0.35 & 0.50 to 2.00 \\
\hline
\end{tabular}

Table 3 - UNS S32760 and E2595-15 composition ranges.

\begin{tabular}{|c|c|c|c|c|c|c|c|c|c|c|c|c|}
\hline \multirow{2}{*}{$\begin{array}{c}\text { Base or filler } \\
\text { metal }\end{array}$} & \multicolumn{8}{|c|}{ Chemical Composition Range, Weight \% (single value is a maximum) } \\
\cline { 2 - 13 } & $\mathrm{C}$ & $\mathrm{Mn}$ & $\mathrm{P}$ & $\mathrm{S}$ & $\mathrm{Si}$ & $\mathrm{Cr}$ & $\mathrm{Ni}$ & $\mathrm{Mo}$ & $\mathrm{N}$ & $\mathrm{Cu}$ & $\mathrm{W}$ \\
\hline UNS S32750 & 0.030 & 1.20 & 0.035 & 0.020 & 0.80 & 24.0 to 26.0 & 6.0 to 8.0 & 3.0 to 5.0 & 0.24 to 0.32 & 0.50 & -- \\
\hline E2595-15 & 0.04 & 2.5 & 0.03 & 0.025 & 1.2 & 24.0 to 27.0 & 8.0 to 10.5 & 2.5 to 4.5 & 0.20 to 0.30 & 0.4 to 1.5 & 0.4 to 1.0 \\
\hline
\end{tabular}

$\mathrm{N}$ alloy, and, by beginning diffusion and transformation at the higher temperature, molybdenum and chromium can diffuse more rapidly and have somewhat longer time to do so. It should also be noted in Figure 3(a) that the original coarse ferrite grain size has been broken up by the formation of austenite platelets throughout the original ferrite grains. With the ferrite grains broken up into smaller units by the austenite platelets interior to the original ferrite grains, toughness is improved. And without chromium nitride precipitates, corrosion resistance is improved. The same situation occurs in the hottest part of the HAZ. As a result it can be concluded that the higher nitrogen UNS S32205 composition of Figure 3 is clearly superior to the lower nitrogen UNS S31803 composition of Figure 2.

Accordingly, it should be abundantly clear that UNS S31803 is an inappropriate base metal specification for service in the as-welded condition. UNS S32205 should be specified instead.

UNS S31803 is not the only inappropriate base metal specification for welded fabrication among the duplex stainless steels. The same situation exists with the alloy commonly known as 255, under the composition limits of UNS S32550. Table 2 compares the composition limits of UNS S32550 with those of UNS S32520, which overlap quite substantially. But the minimum nitrogen of UNS S32520 is considerably higher than that of UNS S32550, so that it should be abundantly clear that UNS S32520 is a superior specification for use in the aswelded condition. Alternately, one could use the UNS S32550 specification but restrict nitrogen to the upper part of the composition range.

\section{Pitfall 2: Inappropriate Welding Heat Input}

The conventional wisdom, as regards welding heat input, is that, for welding of the $22 \%$ chromium DSS alloys, heat input should be restricted to 0.5 to $2.5 \mathrm{~kJ} / \mathrm{mm}$ [2], and for welding of the $25 \%$ chromium SDSS, heat input should be restricted to the range of 0.5 to $1.5 \mathrm{~kJ} / \mathrm{mm}$ [3]. The lower heat input limit is imposed due to inadequate formation of austenite, even with high nitrogen alloys, under very rapid cooling rates. The upper heat input limit is imposed due to a tendency for precipitation of intermetallic compounds within the ferrite under slow cooling conditions, a tendency which is greater in $25 \% \mathrm{Cr}$ SDSS than it is in $22 \%$ Cr DSS.

Karlsson notes that the tendency for precipitates to form during welding, in the higher nitrogen $22 \%$ Cr DSS such as UNS S32205, is low enough that there is little risk as long as the heat input restriction noted above is followed [6]. However, he notes further that, with the $25 \% \mathrm{Cr}$ SDSS, even the restriction of welding heat input to 0.5 to $1.5 \mathrm{~kJ} / \mathrm{mm}$ does not guarantee freedom from precipitates in a multipass weld. Multiple weld reheating cycles can produce precipitation of chromium nitrides, secondary austenite and various intermetallic compounds including sigma phase in these highly alloyed steels.

An example of inappropriate welding heat input in 25\% Cr SDSS from the author's personal experience involved UNS S32750 (popularly known as Alloy 2507) multipass welded with AWS A5.4/A5.4M class E2595-15 covered electrodes. Table 3 lists the composition ranges of the base metal and electrode specifications. Note that the filler metal includes small additions of $\mathrm{Cu}$ and $\mathrm{W}$, and otherwise matches the composition of the base metal except that the filler metal, as is common practice, is enriched in nickel to promote austenite formation in the aswelded condition. This filler metal/base metal combination is recommended by many filler metal manufacturers.

The plate thickness for the procedure qualification tests was $9.5 \mathrm{~mm}$. The joint preparation was a single- $\mathrm{V}$ groove, 60 degree included angle with a $1.5 \mathrm{~mm}$ root opening and a $3 \mathrm{~mm}$ root face. For the original procedure qualification tests, $3.2 \mathrm{~mm}$ electrodes were used. After filling the groove with 10 weld passes, the root side was back-gouged to sound metal and finished with 2 passes. Welding heat input averaged about $0.7 \mathrm{~kJ} / \mathrm{mm}$ for all passes. Sub-size ( $8 \mathrm{~mm}$ thick) Charpy V-notch specimens were taken from the weld metal and HAZ and tested at $-40^{\circ} \mathrm{C}$. The impact test requirement was $27 \mathrm{~J}$, which the HAZ comfortably exceeded. But in the initial test and in a repeat test of the weld metal, two of three Charpy V-notch specimens failed to meet 27 J.

Samples of the weld from the procedure qualification test were examined in a scanning electron microscope to determine the cause of the low weld metal impact test results. Figure 4 shows the microstructure of the weld metal near the mid- 
thickness of the test coupon. Extensive angular precipitates, within the ferrite only, are readily apparent. No attempt was made to identify exactly which precipitates are present. It was concluded that the precipitation was brought about by the numerous reheat cycles involved in welding the test coupon in a total of 12 passes.

Accordingly a new procedure qualification test was conducted, using the same joint design and electrodes. But the welding travel speed was reduced so that the welding heat input was about 1.2 to $1.3 \mathrm{~kJ} / \mathrm{mm}$, and the joint was completed in 4 weld passes from the top side and a single pass in the back-gouged root. The same sub-size Charpy V-notch impact specimens averaged about $45 \mathrm{~J}$ at $-40^{\circ} \mathrm{C}$, comfortably exceeding the $27 \mathrm{~J}$ requirement. The microstructure was found to be virtually free of all precipitates.

Root runs in pipe present a special case of inappropriate heat input possibilities. Welders of carbon steel pipes are trained to make the root run at rather high travel speed, usually using cellulosic electrodes in the vertical-down method, and to follow this up with a high heat input "hot pass" which serves to prevent hydrogen induced cracking in the carbon steel. But a low heat input root pass followed by a higher heat input "hot pass" tends to overheat the root pass and result in precipitation of intermetallic compounds in the root pass of SDSS. Since the root pass surface is the one usually exposed to the corrosive media in service, this can be a very dangerous situation. Intermetallic compounds buried within the joint away from an exposed surface, although they are damaging to toughness, are not nearly as dangerous as intermetallic compounds in the root pass because the former are not normally exposed to the corrosive media, while the latter are. A good practice with DSS and especially SDSS pipe is to put in the root pass with more heat input than the first few fill passes [7-8]. A root pass of about $6 \mathrm{~mm}$ thickness has been found to work well [7].

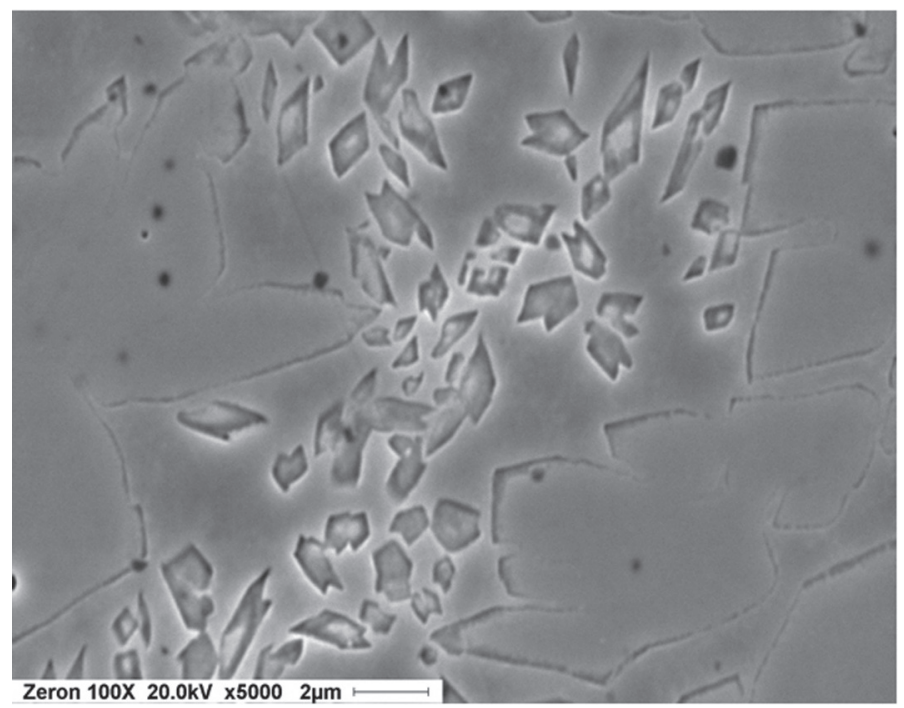

Figure 4. Angular precipitates in the ferrite of E2595-15 reheated weld metal.

\section{Pitfall 3: Inappropriate Postweld Heat Treatment}

If a welded casting, or a welded and formed head, requires postweld heat treatment, the usual nickel-enriched filler metal, combined with inappropriate annealing temperature that meets base metal specifications, offers another pitfall for the DSS fabricator. $(9 \% \mathrm{Ni}$ is common in otherwise matching filler metals for DSS, as indicated for the E2595-15 filler metal in Table 3.) There is some variation in annealing requirements, but a common requirement is for annealing at $1040^{\circ} \mathrm{C}$, minimum, followed by water quench from the annealing temperature [9]. The pitfall stems from the not-well-known fact that higher nickel raises the solvus temperature for the sigma phase that almost invariably forms in DSS during heating towards the annealing temperature. The nickel-enriched weld metal alone is at risk in this situation.

Figure 5 shows the effect of nickel on the sigma solvus temperature for $25 \% \mathrm{Cr}-3.5 \%$ Mo alloys, as given by Grobner [10]. While the alloys used in developing this diagram did not include alloy elements such as $\mathrm{Mn}, \mathrm{Si}$ and $\mathrm{N}$, it is qualitatively suitable for understanding the effect of nickel. It clearly shows that the sigma solvus temperature increases with increasing nickel content. In particular, it indicates that the sigma solvus temperature can be expected to be at least $50^{\circ} \mathrm{C}$ higher for a $9 \%$ $\mathrm{Ni}$ weld metal than for an otherwise matching composition base metal containing $5 \% \mathrm{Ni}$.

Figure 5 also applies qualitatively to $22 \% \mathrm{Cr}$ alloys such as 2205 welded with enriched Ni filler metal of otherwise matching composition, as shown by Figure 6 from Kotecki [11]. This weld metal contained $8.3 \% \mathrm{Ni}$. It was annealed at $1040^{\circ} \mathrm{C}$ for 96 hours, out of concern that sigma forming during heating to the annealing temperature would be slow to dissolve at the annealing temperature. Extensive sigma is clearly present after water quenching from the annealing temperature. It must be concluded that sigma is stable in this composition at $1040^{\circ} \mathrm{C}$. Note that the microstructure is relatively coarse as compared to that which will be shown later, due to the long annealing time.

Figure 7 shows weld metal matching Alloy 255 composition exactly $(5.8 \% \mathrm{Ni})$, also taken from Kotecki [11]. This weld metal was annealed only 4 hours at $1040^{\circ} \mathrm{C}$ before water quench, and it contains no sigma. It was quite ductile ( $34 \%$ elongation in a $4: 1$ gauge length to diameter ratio tensile test).

However, when an Alloy 255 weld metal, of otherwise matching composition but enriched in nickel to $9 \%$, was annealed at $1040^{\circ} \mathrm{C}$ and water quenched, the result was extensive sigma phase throughout the microstructure, as shown in Figure 8, also taken from Kotecki [11]. The sigma phase appears grey in Figure 8, with austenite clear and ferrite black. The weld metal was quite brittle, exhibiting only $7 \%$ elongation (versus $26 \%$ elongation in the as-welded condition). It is noteworthy that the as-welded ferrite content of this $9 \% \mathrm{Ni}$ weld metal was $54 \mathrm{FN}$, but after the "anneal" at $1040^{\circ} \mathrm{C}$, the $\mathrm{FN}$ had dropped to 28 , indicating that about half of the original ferrite had become sigma as a result of this heat treatment. That agrees qualitatively with the microstructure shown in Figure 8. The same 9\% Ni weld metal, annealed at $1150^{\circ} \mathrm{C}$, cooled to $1040^{\circ} \mathrm{C}$ in the furnace and held at $1040^{\circ} \mathrm{C}$ for only 30 minutes, then water quenched before 
any sigma could nucleate, measured $45 \mathrm{FN}$ and exhibited 35\% tensile elongation, with no sigma phase in the microstructure. This "step-anneal" allowed for near equilibrium partitioning of nitrogen, which has been claimed by the purveyors of Alloy 255 as being essential for optimum corrosion resistance of the base metal. It is quite clear from this work that the enriched nickel filler metals require higher annealing temperature than the base metal in order to avoid damage from sigma phase.

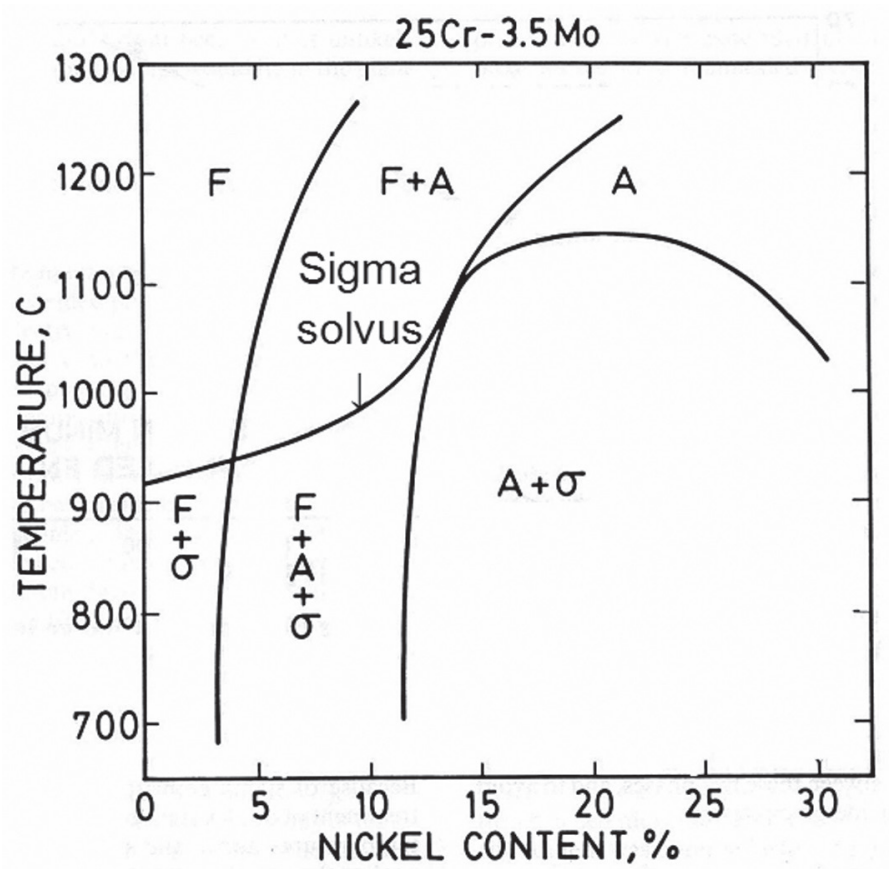

Figure 5. Grobner Diagram.

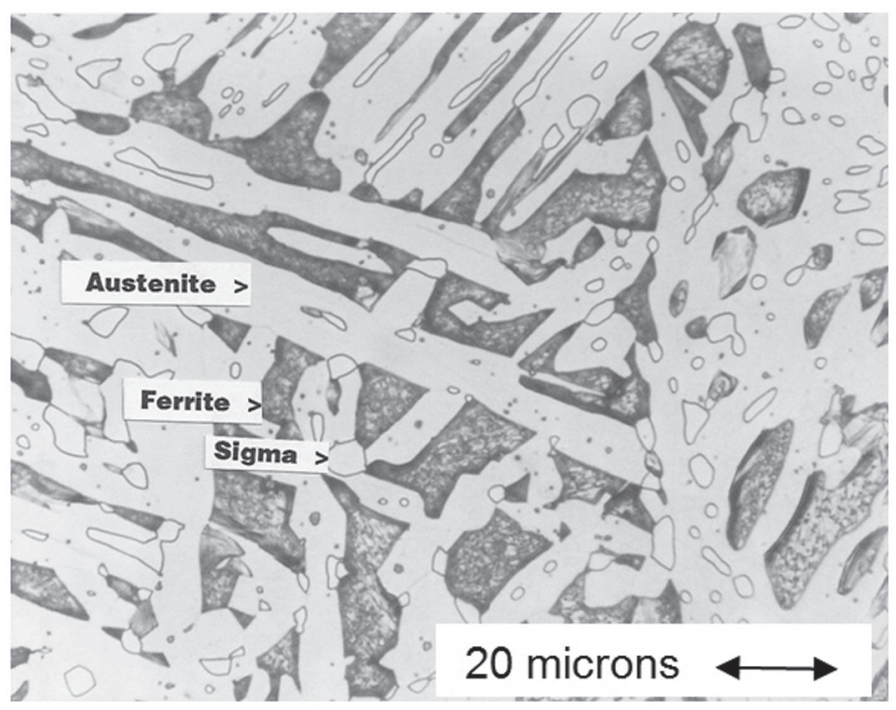

Figure 6. 2209 Weld Metal Annealed 96 hours at $1040^{\circ} \mathrm{C}$.

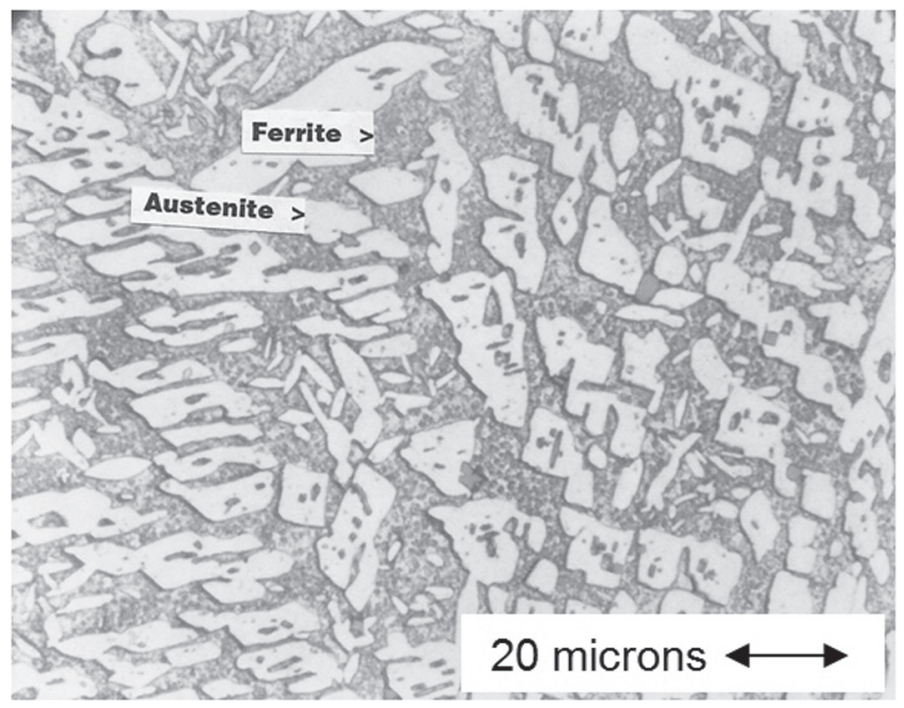

Figure 7. Alloy 255 Weld Metal of 5.8\% Ni, Annealed 4 hours at $1040^{\circ} \mathrm{C}$.

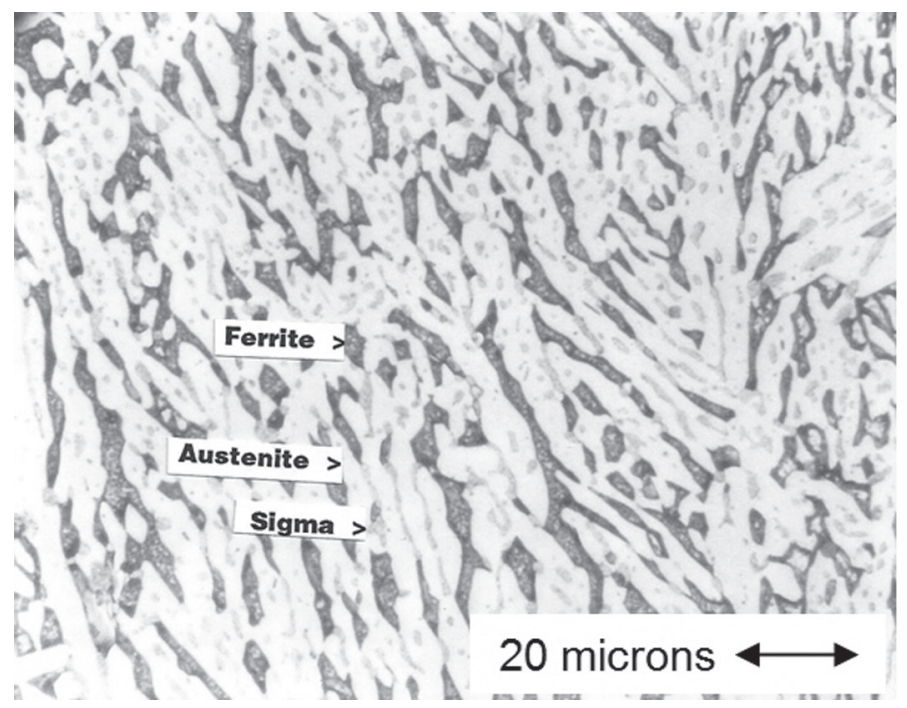

Figure 8. Alloy 255 Weld Metal of 9\% Ni, Annealed 4 hours at $1040^{\circ} \mathrm{C}$.

\section{Conclusion}

Duplex stainless steels, including SDSS, have proven to be very useful engineering materials, with generally good weldability. However, there are some pitfalls for the unwary or uninformed. For the sake of good properties in the HAZ and in autogenous weld metal, it is appropriate to specify base metals of high nitrogen content, at least $0.14 \%$. Otherwise, excessive ferrite is likely at least in the HAZ, and chromium nitrides may precipitate, damaging both corrosion resistance and mechanical properties. For the sake of avoiding precipitations in multiple reheated zones of SDSS, it is appropriate to avoid a large number of low heat input, small weld passes. Furthermore, root passes in DSS and SDSS pipe should be made with higher heat input (over $1 \mathrm{~kJ} / \mathrm{mm}$ ) than the first few subsequent passes to avoid precipitations at the inside surface of the pipe. And postweld 
annealing of welded DSS needs to take into account the fact that sigma dissolution in weld metal of enriched nickel content requires higher temperatures than the base metals.

\section{References}

[1] Solomon H.D., Devine T.M. Jr.:1983. Duplex Stainless Steels, Paper 8201-089, Duplex stainless steels - A tale of two phases, American Society for Metals, Materials Park, Ohio, USA

[2] Larsson B., Lundqvist B, 1987. Fabricating ferriticaustenitic stainless steels, second edition, Sandvik R\&D Centre report.

[3] Stevenson A.W., Gough P.G., Farrar J.C.M.,1991. The weldability of super duplex alloys - Welding consumable and procedure development for Zeron 100, International Institute of Welding International Conference, Den Haag, Netherlands.

[4] ASTM A 240/A 240M:2000. Standard Specification for Chromium and Chromium-Nickel Stainless Steel Plate, Sheet, and Strip for Pressure Vessels and for General Applications, ASTM International, USA.

[5] Ogawa T., Koseki T., 1989. Effect of composition profiles on metallurgy and corrosion behavior of duplex stainless steel weld metals, Welding Journal, V68 N5, pp 181-s to 191-s.

[6] Karlsson L., 1999. Intermetallic phase precipitation in duplex stainless steels and weld metals: Metallurgy, influence on properties, welding and testing aspects, WRC Bulletin 438, Welding Research Council, Shaker Heights, Ohio, USA.

[7] van Nassau L., Meelker H., Neesen F., Hilkes J., 1997. Welding duplex and superduplex stainless steel, Duplex Stainless Steels 97 conference proceedings, pp 17 to 28, KCI Publishing BV, Zutphen, The Netherlands.

[8] Baxter C., Young M., 2000. Practical aspects for production welding and control of duplex stainless steel pressure and process plants, Duplex America 2000 Conference proceedings, pp129 to 137, KCI Publishing BV, Zutphen, The Netherlands.

[9] ASTM A 890/A 890M:2003. Standard Specification for Castings, Iron-Chromium-Nickel-Molybdenum CorrosionResistant, Duplex (Austenitic/Ferritic) for General Application, ASTM International, USA.

[10] Grobner P.J., 1985. Phase relations in high molybdenum duplex stainless steels and austenitic corrosion resistant alloys, Report RP-33-84-01/82-12, AMAX Metals Group, Ann Arbor, Michigan, USA.

[11] Kotecki D.J., 1989. Heat Treatment of duplex stainless steel weld metal, Welding Journal, V68 N11, pp 431-s to 441-s. 